\title{
СУЧАСНІ МЕТОДИ РЕАБІЛІТАЦЇ̈ ХВОРИХ ІЗ ЗАКРИТОЮ ТРАВМОЮ КОЛІННОГО СУГЛОБА
}

\author{
П. П. Новікова \\ Медичний центр «Клініка сучасної ортопедї̈, м. Київ
}

У статті висвітлено основні принципи застосування методів реабілітаційного лікування хворих 3 ушкодженнями колінного суглоба. Значну увагу приділено методології проведення медичної реабілітації у лікарняний та післялікарняний періоди.

\section{MODERN METHODS OF REHABILITATION OF PATIENTS WITH CLOSED INJURY OF KNEE JOINT}

\author{
P. P. Novikova \\ Medical Center «Clinic of Modern Orthopedics», Kyiv
}

The article describes the basic principles of the application of methods of rehabilitation treatment of patients with knee joint injuries. Considerable attention is paid to the methodology of medical rehabilitation in the hospital and post-hospital period.

Вступ. Травми опорно-рухового апарату спостерігають досить часто, особливо у спортсменів. До 50-70 \% всіх травм складають травми колінного суглоба [1]. Це пов'язано з його анатомічними особливостями (недостатній м'язовий захист, відсутність фіксуючих кісткових утворень) і збільшеними вимогами у спортсменів і людей інших професій [2]. Ушкодження менісків (надриви, розриви, роздавлювання) часто супроводжуються ушкодженням обхідних і хрестоподібних зв'язок. Комбіноване ушкодження внутрішнього меніска, обхідної великогомілкової та передньої хрестоподібної зв'язок отримало назву в травматології «нещасної тріади», яку нерідко діагностують у спортсменів ігрових видів спорту.

Основна частина. Медична реабілітація $є$ фундаментом реабілітаційного процесу. Від ії ефективності залежить використання подальших видів реабілітації, їх тривалість та обсяг. Медична реабілітація спрямована на відновлення здоров'я, ліквідацію патологічного процесу, запобігання ускладненням, відновлення або часткову компенсацію порушених функцій, протидію інвалідності, підготовку тих, які одужують, та людей з обмеженими можливостями до побутових і трудових навантажень завершується у медичних закладах.

(с) П. П. Новікова, 2018
Складовою частиною медичної реабілітації $\epsilon$ фізична реабілітація. Вона мобілізовує резервні сили організму, активізовує його захисно-пристосувальні механізми, запобігає ускладненням, прискорює відновлення функцій різних органів і систем, скорочує терміни клінічного і функціонального відновлення, адаптовує до фізичних навантажень, тренує і загартовує організм, відновлює працездатність. Залежно від характеру, перебігу та наслідків захворювання або травми, періоду і етапу відновного лікування фізичну реабілітацію використовують з профілактичною або лікувальною метою і займає допоміжне чи головне місце у комплексі взаємодоповнюючих лікувальних заходів медичної реабілітації.

У медичній реабілітації, згідно з рекомендаціями експертів ВоО3, розрізняють два періоди: лікарняний та післялікарняний. В кожному з них $є$ визначені етапи, у першому лікарняному один етап - І етап реабілітації - лікарняний (стаціонарний), а другому післялікарняному періоді два етапи - II етап поліклінічний або реабілітаційний, санаторний та III етап диспансерний [3].

Медична реабілітація - комплекс заходів, що включає способи прискорення реституції, стимуляції репаративно-регенеративних процесів, виявлення 
та зміцнення компенсаторних механізмів, корекції загальної резистентності організму та імунітету.

Засоби медичної реабілітації: медикаментозна терапія, відновна та косметична хірургія, фізіотерапія та ЛФК, психотерапія, дієтотерапія, комплементарні методи (акупунктурна терапія, мануальна терапія, фітотерапія, гомеопатія, еферентна терапія) [4].

В останні роки хірурги-травматологи при ушкодженні менісків і зв'язкового апарату колінного суглоба проводять артроскопічну операцію, яка стала «золотим стандартом» лікування. Переваги артроскопії в порівнянні з артротомією полягають в меншій травматизації, скорочені періоду непрацездатності, та періоду перебування в стаціонарі, зменшенні кількості ускладнень (кровотечі, інфікування та ін.).

Медикаментозну терапію використовують при запальних процесах (нестероїдні протизапальні препарати: диклофенак натрію, диклофенак ретард та ін.) та при ушкодженні хряща (препарати, які містять глюкозаміну сульфат та хондроїтину сульфат рослинного або тваринного походження).

Широко використовують кріотерапію, особливо після заняття фізичними вправами для профілактики набряку колінного суглоба та зменшення болю.

Масаж, надаючи знеболювальну дію, покращує функцію і швидше відновлює опорну та рухову функції суглоба, зв'язкового апарату, прискорює процеси регенерації тканин, запобігає розвитку сполучнотканинних зрощень, контрактур і м'язової атрофії. Масаж призначають за трьома періодами перебігу хвороби: раннім післяопераційним, пізнім післяопераційним і відновно-тренувальним.

Для покращення кровопостачання в ушкодженій кінцівці в ранній післяопераційний період рекомендовано проводити масаж за декількома методиками:

- масаж рефлекторної зони (при травмах колінного суглоба), сегментарно-рефлекторний масаж паравертебральних зон - спинномозкових сегментів S5-S1 i L5-L1);

- масаж колатеральної кінцівки (здорової симетричної) з використанням усіх прийомів;

- масаж проксимальних ділянок оперованої кінцівки (відсмоктувальний) з 10-12-го дня після операції.

Тривалість процедури - 10 хв.

У другий, пізній післяопераційний, період рекомендують призначати масаж стегна, гомілки та колінного суглоба, пасивні й активні рухи в суглобі ушкодженої ноги. Використовують усі масажні прийоми. Для ліквідації атрофії чотириголового м'яза стегна вибірково масажують м'язи стегна, що приводять і розгинають нижню кінцівку. Тривалість процедури - 10-15 хв щоденно.

У третій, відновно-тренувальний, період після ушкодження менісків і зв'язок масаж показаний у разі залишкових явищ після ушкодження у вигляді тугорухомості або контрактур суглоба й атрофії м'язів стегна. Рекомендують продовжувати масаж паравертебральних зон - спинномозкових сегментів S5-S1, L5-L1, а також масаж колінного суглоба - циркулярне погладжування, розтирання, ніжні вібрації, зрушення та розтягування м'яких тканин, спаяних із кістковою мозолею. При атрофії м'язів застосовують прийоми стимуляції - пасивні розтягнення та скорочення м'язів і сухожиль у швидкому темпі, потрушування та струшування. Якщо виражена контрактура колінного суглоба, то рекомендують використовувати погладжування та розтирання періартрикулярних тканин; масаж сумковозв'язкового апарату - кінцями пальців і щипцеподібне погладжування скорочених і розслаблених зв'язок, розтирання, безперервна вібрація. Закінчують масаж загальними широкими штриховими погладжуваннями хворої кінцівки, пасивними й активними рухами. Тривалість процедури - 10-15 хв.

Фізіотерапевтичні процедури відіграють важливу роль у комплексній реабілітації осіб після артроскопічних операцій. В перший ранній післяопераційний період фізіотерапевтичні процедури надають могутню трофічну, протизапальну та знеболювальну дії, деякі з них сприяють швидкій регенерації хрящової тканини. У подальші періоди фізіотерапевтичні заходи сприяють: покращенню окисно-відновних і трофічних процесів у суглобах, збільшенню амплітуди рухів, розтягненню та покращенню еластичності м'язів і зв'язок, відновленню сили м'язів і функції суглоба.

Фізіотерапевти рекомендують у перший післяопераційний період ушкоджень використовувати методи світлотерапії, застосовуючи інфрачервоне й ультрафіолетове випромінювання паравертебральних зон хребта і симетричної здорової нижньої кінцівки суберитемними й еритемними біодозами (з 2-3 біодоз із подальшим збільшенням експозиції). Для зняття больового синдрому після травм застосовують діадинамотерапію. У подальшому використовують розсмоктувальну властивість діадинамотерапії при лікуванні рубців, м'язових контрактур, обмеженні рухливості суглобів після їх тривалої іммобілізації. Також травмованим показані: електрофорез із новокаїном та іншими знеболювальними ліками, магнітотерапія. 
У другий, пізній післяопераційний, період використовують такі апаратні методи, які здатні викликати тепло в тканинах безконтактним способом: індуктотермія, інфрачервоне випромінювання, мікрохвильова терапія, парафінові й озокеритові аплікації. При зменшенні болю рекомендують підключати методи ультразвукової та лазерної терапії паравертебральної зони та ділянки колінного суглоба.

У третій, відновний період, разом із електролікуванням, лазеро- та магнітотерапією, фізіотерапевти рекомендують широко використовувати грязелікування та бальнеотерапію - радонові, сірчано-водневі, хлоридно-натрієві ванни.

Лікувальна гімнастика - головна форма ЛФК. Вона розв'язує основні завдання лікувальної дії фізичних вправ. У комплекс лікувальної гімнастики включають загальнорозвиваючі та спеціальні вправи. Співвідношення їх залежить від характеру захворювання чи травми, методу лікування, клінічного перебігу хвороби і стану хворого, рухового режиму і періоду застосування ЛФК, етапу реабілітації.

І період (вступний) - щадний, характеризується вираженими анатомічними і функціональними порушеннями ушкодженого органа. Рекомендовані вправи: ізотонічні напруження м'язів стегна та пасивні рухи оперованої кінцівки, дихальна гімнастика, вправи для рук і плечового пояса, здорової кінцівки.

II період (основний) - функціональний, характеризується покращенням клінічного стану хворого, відновленням анатомічної цілісності органа чи тканин при одночасному суттєвому порушенні їх функції. Рекомендовані вправи: ізотонічні напруження м'язів стегна, які поступово замінюються динамічними рухами з навантаженням, активне згинання та розгинання суглоба, загальні вправи з використанням тренажерів.

\section{СПИСОК ЛІТЕРАТУРИ}

1. Готовцев П. И. Лечебная физическая культура и массаж/ П. И. Готовцев, А. Д. Субботин, В. П. Селиванов. М. : Медицина, 1987. - 304 с.

2. Колінний суглоб (променева анатомія, методи дослідження, променева діагностика захворювань і травматичних ушкоджень) / М. І. Спузяк, О. П. Шармазанова, Р. Я. Абдуллаєв [та ін.]. - Донецьк : Видавець Заславський О. Ю., 2011. - 208 с.

3. Магльований А. Основи фізичної реабілітації / А. Магльований, В. Мухін, Г. Магльована. - Львів, 2006. - 150 с.

4. Сучасні стандарти та критерії в галузі реабілітаційної медицини : навч. посіб. / за ред. В. П. Лисенюка. - К., 2001. - 70 c.
III період (заключний) - тренувальний характеризується завершенням процесу одужання, відновленням функцій, але здатність витримувати життєві навантаження ще недостатня. Завдання на цьому етапі реабілітації - адаптація до повільного бігу, відновлення максимальної сили м'язів стегна, часткове відновлення специфічних рухових навичок спортсмена. Крім загальнозміцнювальних вправ у заняття включається повільний біг спочатку на тредбані, а після двох-трьох тренувань - повільний біг у природних умовах. Спортсмени ігрових видів спорту виконують вправи з м'ячем на місці (прийом і передача волейбольного, футбольного, баскетбольного м'яча). Спортсмени групи єдиноборств виконують імітаційні вправи з урахуванням їх виду спорту.

Механотерапія - лікування фізичними вправами за допомогою спеціальних апаратів. На них виконують точно спрямовані та суворо дозовані рухи, метою яких $є$ відновлення рухомості у суглобах і зміцнення сили м'язів.

Гідрокінезотерапія - лікувальна в басейнах із теплою термальною або морською водою. Вправи підбирають індивідуально, залежно від фізичного стану організму та етапу реабілітації. Підйомна сила води сприяє виконанню вправ, які в інших умовах викликали б труднощі, опір води робить рухи інтенсивнішими.

Висновки. Травми колінного суглоба характеризуються високим рівнем інвалідності та великими економічними затратами, які зазнає родина постраждалого та держава. Тому реабілітація хворих із закритими травмами колінного суглоба вимагає комплексу реабілітаційних заходів для швидшого відновлення працездатності. Не остання роль в процесі реабілітації належить медичній сестрі.

5. Без'язична О. В. Використання масажу та фізіотерапії після артроскопічних операцій на колінному суглобі / О.В.Без'язична // Слобожанський науково-спортивний вісник. - 2014. - № 3. - С. 23-25.

6. Гончарук Н. В. Комплексна фізична реабілітація жінок першого зрілого віку після артроскопічної операції з приводу комбінованого ушкодження меніску та зв'язок колінного суглоба в умовах поліклініки / Н. В. Гончарук, О. В. Без'язична, О. А. Дмитренко // Слобожанський науково-спортивний вісник. - 2014. - № 3. - С. 40-44. 